\title{
Societies' Proceedings
}

speaker) had used something rather like it for some time. He found that after defibrinating plasma to procure serum there was left in the centre a considerable mass of fibrin. This was removed and ironed out into a sheet and by wrapping up the severed nerve in this the ends could be held together without sutures. The adhesion was surprisingly firm and no sutures were required. Much of this fibrin was being poured away at the present time. He used it in another way. Mr. Cawthorne had mentioned the use of gold leaf, but the speaker used the fibrin to cover up the whole of the mastoid cavity after operation. It could be used in any thickness. Another advantage was that it was a most efficient styptic. For instance, when a bone structure was oozing and full of blood clot, the fibrin was pressed in, glued itself to the bone and all oozing immediately ceased.

\section{OBITUARY}

\author{
MARKUS HAJEK \\ I862-I94I
}

Professor Hajek died in London on April 3rd. He was the last survivor of the far-famed group of Professors of Laryngology who made Vienna the Mecca of the specialty for more than seventy years. It was in I855 that Garcia invented laryngoscopy and only three years later that Türck demonstrated the clinical application and value of the new method in his Vienna clinic. Schrötter, Stoerck and Chiari followed him in the chair and taught successive generations of laryngologists, particularly British and American ones. Equally famous were the professors of Otology, particularly Gruber and Politzer. It was when the chairs of Laryngology and Otology were combined that one of the clinics was put in charge of Hajek, who had already made a name for himself at the Policlinik. Schnitzler was the director of this and his daughter became Hajek's devoted wife. Her brother was Arthur Schnitzler, the well-known dramatist. Hajek's early work was mainly concerned with the anatomy of the nasal accessory sinuses, of which he made numerous dissections and specimens. Many will remember how clearly they helped to illustrate his lectures and demonstrations. When he was forced to leave Vienna practically penniless, owing to the savage persecution of the Jews in 1938, he sought refuge in London and was gladly welcomed by his British colleagues. He brought with him fourteen of his most valued specimens, all he was able to save, and these he presented to the Museum of the Royal College of Surgeons. They included such conditions as a deep excavation of the alveolar process and of deep alveolar sinuses, double-sided sinus palatinus, asymmetry of the frontal and sphenoidal sinuses, abnormally narrow 


\section{Obituary}

and tortuous nasolachrymal duct, large openings of the ethmoid and of several external infundibular cells, irregular forms of the Hiatus semilunaris atypical cells spreading into the middle turbinated body and many other anomalies. Hajek demonstrated these at a meeting of the Section of Laryngology of the Royal Society of Medicine at the sessions of which he was a regular attendant and one of its very few honorary members. Although Hajek's fame rests mainly on his work on the accessory sinuses of the nose which is embodied in his volumes on Diseases of the Nose, now translated into many languages, he made many contributions of importance to Laryngology and published a two volume work on diseases of the larynx, with many illustrations of his beautiful dissections and in clinical material. It was, however, his world-wide reputation as a teacher that drew so many students to his clinic and it was perhaps his greatest interest. His enthusiasm never flagged and he took the greatest pains to engage and stimulate his students. Clarity of exposition and wealth of clinical material as well as a profound knowledge of his subject were additional factors in his success. His life was bound up in his clinic and it was only after life in Vienna became unbearably savage that he sought refuge in England. It was a privilege for his British colleagues to do something to temper the bitterness of the last years of one who may justly be described as un grand maitre.

W.G.H. 